\title{
Effects of sexual maturation and gonadal steroids on the localization of IgG-, IgM- and IgA-positive cells in the chicken oviduct
}

\author{
W. M. Zheng ${ }^{1}$, Y. Yoshimura ${ }^{1 *}$ and T. Tamura ${ }^{2}$ \\ ${ }^{1}$ Graduate School for International Development and Cooperation, and ${ }^{2}$ Faculty of Applied Biological \\ Science, Hiroshima University, Higashi-Hiroshima 739, Japan
}

\begin{abstract}
The effects of sexual maturation and gonadal steroids on the localization of immunoglobulin-positive cells in chicken oviducts were studied. Oviductal tissues were collected from laying hens and chicks treated with stilboestrol (DES, an analogue of oestrogen) or progesterone. Paraffin wax sections of the tissues were immunostained for $\operatorname{IgG}$, IgM and IgA, and the frequency of cells staining positive was examined using an image analysis system. Some of the cells in the mucosal epithelium and plasma cell-like cells in the stroma of the oviduct stained positive for $\operatorname{IgG}$ IgM or IgA. In the mucosal epithelium of laying hens, there was a significantly greater number of IgG-positive $\left(\mathrm{IgG}^{+}\right)$cells in the shell gland than in the infundibulum, magnum and isthmus, more $\lg \mathrm{M}^{+}$cells in the magnum than in the infundibulum, and more $\operatorname{Ig} \mathrm{A}^{+}$cells in the magnum than in the other segments of the oviduct with the exception of the vagina. The frequency of $\operatorname{IgG}^{+}$and $\operatorname{IgM}^{+}$cells in the mucosal epithelium of all oviductal segments and $\operatorname{IgA}{ }^{+}$cells in the magnum, isthmus and vagina was significantly higher in laying hens than in immature birds. In the subepithelial stroma of laying hens, there was a significantly greater population of $\operatorname{IgG}^{+}$ cells in the infundibulum and vagina than in the magnum and isthmus, more $\operatorname{IgM}^{+}$cells in the infundibulum than in the magnum, and more $\operatorname{IgA}{ }^{+}$cells in the uterovaginal junction and vagina than in the magnum and isthmus. The frequency of $\operatorname{IgG}^{+}, \operatorname{IgM}^{+}$and $\operatorname{IgA}{ }^{+}$cells in the subepithelium of infundibulum, uterovaginal junction and vagina was significantly greater in laying hens than in immature birds. The number of $\operatorname{IgM}^{+}$cells in all oviductal segments and of $\operatorname{Ig} \mathrm{A}^{+}$cells in the magnum of the mucosal epithelium of the chicks treated with DES increased significantly compared with those of control chicks. In addition, the number of $\mathrm{IgG}^{+}$cells in the shell gland and vagina and of $\operatorname{lgM}^{+}$cells in the vagina of the stroma of DES-treated birds were increased. Treatment of immature birds with progesterone had no effect on the localization of $\mathrm{Ig}^{+}$cells in the oviduct except for a decrease in the number of $\operatorname{lgM}^{+}$cells in the shell gland. These results suggest that the local immunity in the oviduct develops during sexual maturation, possibly under the control of oestrogen.
\end{abstract}

\section{Introduction}

The chicken oviduct consists of the infundibulum, magnum, isthmus, shell gland, uterovaginal junction (UVJ) and the vagina. In the oviduct, egg components that surround the yolk, including albumin, the shell membrane and the egg shell are formed. In addition, spermatozoa entering via the vagina are stored in the sperm-storage tubules in the UVJ (Fujii, 1963; Fujii and Tamura, 1963) before taking part in fertilization which occurs in the infundibulum. The local immune system in the chicken oviduct may play an important role in preventing infection as the vagina opens to the cloaca which contains numerous exogenous pathogens (Shivaprasad et al., 1990; Poppe et al., 1992). The oviductal immune system may also affect the selection, survival and the fertilizing ability of

*Correspondence.

Received 3 March 1997. spermatozoa (Steele and Wishart, 1992; Bakst et al., 1994). It was reported that incubation of spermatozoa with anti-sperm antisera in turkeys drastically reduces the fertilizing ability of the sperm cells (Burke and Rieser, 1972; Burke and Yu, 1979). In the oviduct of laying hens, plasma cells (Van Krey et al., 1987) and Ig-containing cells (Lebacq-Verheyden et al., 1972; Kirk et al., 1989; Kimijima et al., 1990) that may have a role in local immunity have been demonstrated. Yoshimura et al. (1996) reported that immunocompetent cells, including major histocompatibility complex class II positive cells, $\mathrm{T}$ and $\mathrm{B}$ cells and Ig positive $\left(\mathrm{Ig}^{+}\right)$cells, are numerous in the mucosal surface of the oviduct in laying hens, whereas, in moulting hens, they are reduced.

Previous studies in mammals have indicated that oestrogen enhances humoral immune responses (Trawick and Bahr, 1986; Erbach and Bahr, 1988, 1991) and that the local immune system in the reproductive tract is controlled by gonadal steroids (Grossman, 1984). Therefore, it is possible that the immune 
system of the hen's oviduct is affected by the reproductive cycle and influenced by gonadal steroids. However, it is not known whether the presence of $\mathrm{Ig}^{+}$cells in the oviductal wall is under the control of gonadal steroids in hens. The aim of the present study was to determine the changes in the localization of $\operatorname{IgG}^{+}, \operatorname{IgM}^{+}$and $\operatorname{IgA}{ }^{+}$cells in the oviduct of the hen during sexual maturation and the effects of oestrogen and progesterone on these $\mathrm{Ig}^{+}$cells.

\section{Materials and Methods}

\section{Treatment of birds}

Immature and laying White Leghorn hens were kept in individual cages under a light regimen of $14 \mathrm{~h}$ light and $10 \mathrm{~h}$ dark, and provided with feed and water ad libitum. The chicks (50 days old, $n=5$ birds) and mature hens (approximately 260 days old, $n=5$ birds) that were laying more than five eggs in a sequence were used in Expt 1. The laying hens were used $6 \mathrm{~h}$ after oviposition, that is, when there was an egg in the shell gland. In Expt 2, immature chickens (36 days old) were injected i.m. daily with $1 \mathrm{mg}$ stilboestrol (DES, Nacalai Tesque. Inc., Kyoto,) or I mg progesterone (Sigma Co., St Louis, MO) for 7 days. These steroids were dissolved in sesame oil (vehicle) at a concentration of $10 \mathrm{mg} \mathrm{ml}^{-1}$. Control birds received $0.1 \mathrm{ml}$ vehicle. Six birds were used in each group.

All birds were killed by decapitation. The oviduct was pre-fixed in $10 \%(\mathrm{v} / \mathrm{v})$ formalin solution for approximately $15 \mathrm{~h}$, and small pieces (approximately 3-5 mm long) were cut from the middle part of the infundibulum, magnum, isthmus, shell gland, UVJ and vagina, and re-fixed for another $36 \mathrm{~h}$ in the same fixative. Sections were embedded in paraffin wax $(6 \mu \mathrm{m}$ thick) and immunostained for Igs. Some of the sections were stained with haematoxylin and eosin for histological studies.

\section{Immunocytochemistry}

Antibodies. The first antibodies used for the staining of $\mathrm{IgG}^{+}, \operatorname{IgM}^{+}$and $\operatorname{IgA}{ }^{+}$cells were rabbit anti-chicken IgG (O.E.M. Concepts Inc., Tomas River, NJ), goat anti-chicken IgM (Bethyl Lab. Inc., Montgomery, TX) and goat anti-chicken IgA (Bethyl Lab. Inc., Montgomery, TX), respectively. These first antibodies were diluted to a concentration of 1:500 with PBS containing $0.05 \% \quad(w / v)$ BSA. Vector-staining ABC-PO kits (Vector Lab. Inc., Burlingame, CA) for the detection of rabbit $\operatorname{IgG}$ (in the case of detection of $\mathrm{IgG}^{+}$cells) and goat $\operatorname{IgG}$ (for detection of $\operatorname{IgM}{ }^{+}$and $\operatorname{IgA}{ }^{+}$cells) were used to detect the immunoreaction products of the first antibodies.

Immunostaining. Sections were deparaffinized and washed with PBS for $15 \mathrm{~min}(5 \mathrm{~min} \times 3$ times). They were then incubated with normal horse serum (dilution $1: 150$ ) for $15 \mathrm{~min}$ followed by incubation with the first antibody for $2 \mathrm{~h}$. After washing in PBS ( $5 \mathrm{~min} \times 3$ times), they were incubated with the second antibody for $1 \mathrm{~h}$. Sections were then washed in PBS
(5 min $\times 3$ times) and incubated with avidin-biotin-peroxidase complex for $1 \mathrm{~h}$. After washing with PBS (5 min $\times 3$ times), the immunoreaction products were revealed by incubating with a mixture of $0.02 \%(\mathrm{w} / \mathrm{v}) 3,3^{\prime}$-diaminobenzidine tetrahydrochloride and $0.005 \%(\mathrm{v} / \mathrm{v}) \mathrm{H}_{2} \mathrm{O}_{2}$ in $0.05 \mathrm{~mol}$ Tris- $\mathrm{HCl} 1^{-1}$ buffer, $\mathrm{pH}$ 7.6. Sections were then rinsed with water and counterstained with haematoxylin. Control sections were prepared by the same procedure except that the first antibody with normal rabbit (in case of staining for $\mathrm{IgG}^{+}$cells) or goat (in case of staining for $\operatorname{IgM}^{+}$and $\operatorname{IgA}{ }^{+}$cells ) serum, and no positive staining was observed in these sections. All steps were carried out at room temperature.

\section{Observations and analysis of data}

Sections were examined under a light microscope. Populations of cells positive for immunoreactions in the mucosal epithelium and in the stroma were analysed by an image analysis computer system, MacAspect (Mitani Co., Fukui). The subepithelial stroma of $50 \mu \mathrm{m}$ depth from the basal boundary of the mucosal epithelium covered the whole stromal tissue of each oviductal segment in immature chickens regardless of treatment. However, in laying hens, it did not cover the middle part of stroma because the tubular glands had developed there. Therefore, the frequency of positive cells in the stroma was examined in the subepithelial stroma (the area $50 \mu \mathrm{m}$ in depth from the boundary of the mucosal epithelium) of immature hens and in the subepithelial and middle part of the stroma of laying hens. The number of positive cells was counted in two different areas (approximately 5000$15000 \mu \mathrm{m}^{2}$ each) in one oviductal segment of a bird and the values were calculated to be the number of cells in $5000 \mu \mathrm{m}^{2}$. The average of the two counts was then used as the number of cells in one segment of a bird. The significance of difference in the number of cells among treatments or segments was examined by one-way ANOVA followed by Duncan's multiple $t$ test.

\section{Results}

Experiment 1: changes in the $\mathrm{Ig}^{+}$cell population in the oviduct before and after sexual maturation

The mucosal tissue of the oviduct consisted of the mucosal epithelium and stroma in both immature and laying hens. Tubular glands were well developed in the magnum, isthmus and shell gland in laying hens. Plasma cell-like cells in the stromal connective tissues in each oviductal segment stained positive for IgG (Fig. Ia-f), IgM and IgA in both immature and laying hens. Some mucosal epithelial cells also stained positive for IgG (Fig. Ib, d, f), IgM and IgA in laying hens, whereas few of these cells stained in immature hens.

The frequency of $\mathrm{Ig}^{+}$cells in the oviductal mucosal epithelium in laying and immature hens is shown (Fig. 2). In the mucosal epithelium of laying hens, the population of $\mathrm{IgG}^{+}$ cells in the shell gland was significantly higher than that in the infundibulum, magnum or isthmus. The frequency of $\operatorname{IgM}^{+}$ cells in the magnum was significantly higher than that in the infundibulum, and the frequency of $\operatorname{IgA}{ }^{+}$cells in the magnum 
(a)

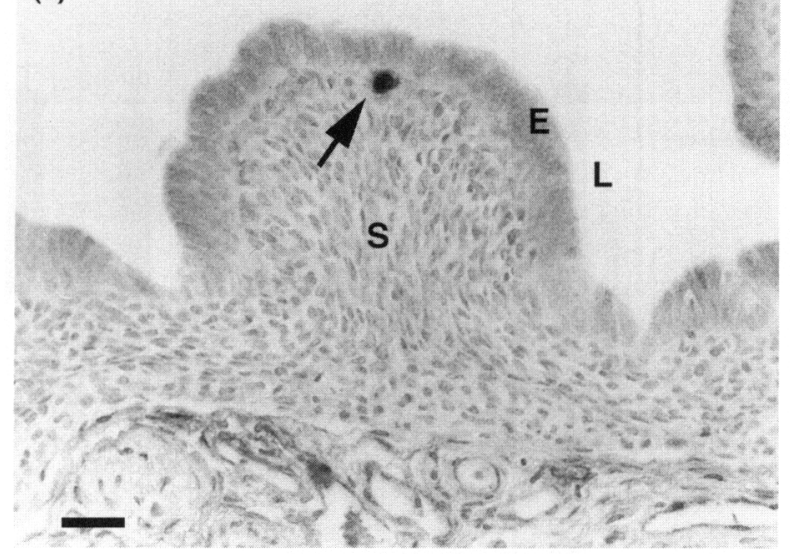

(c)
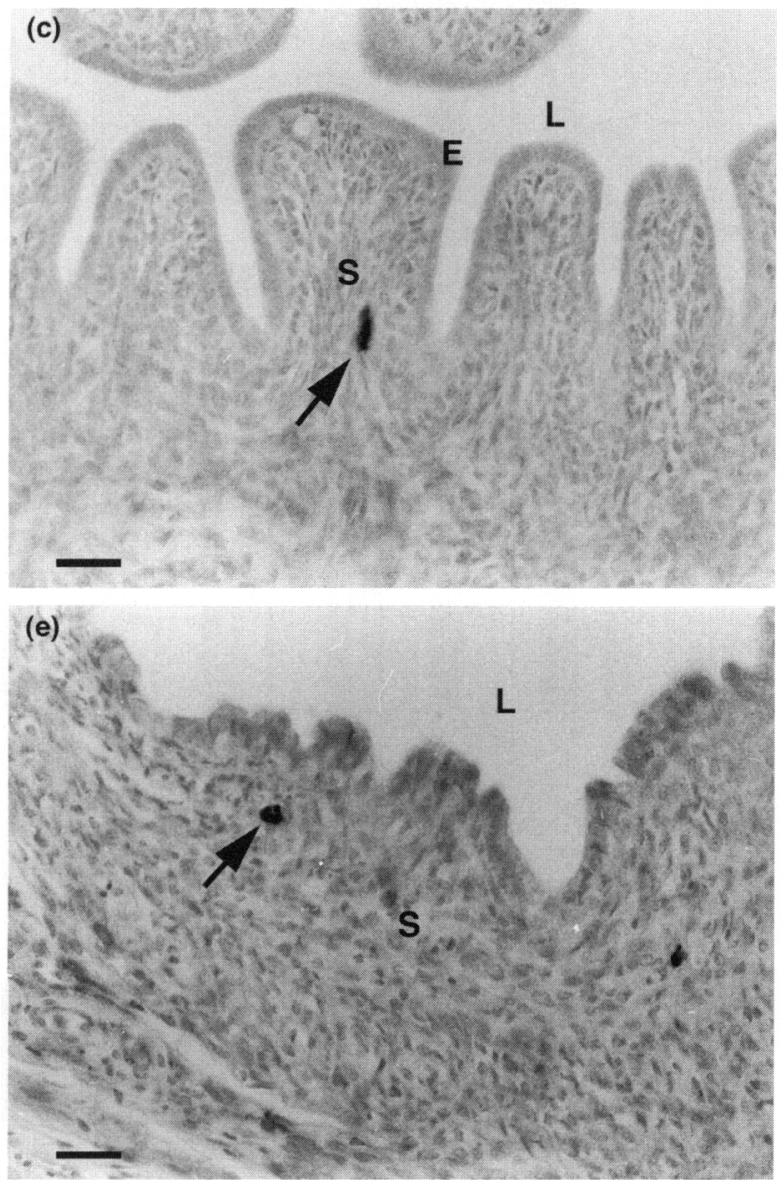

(b)

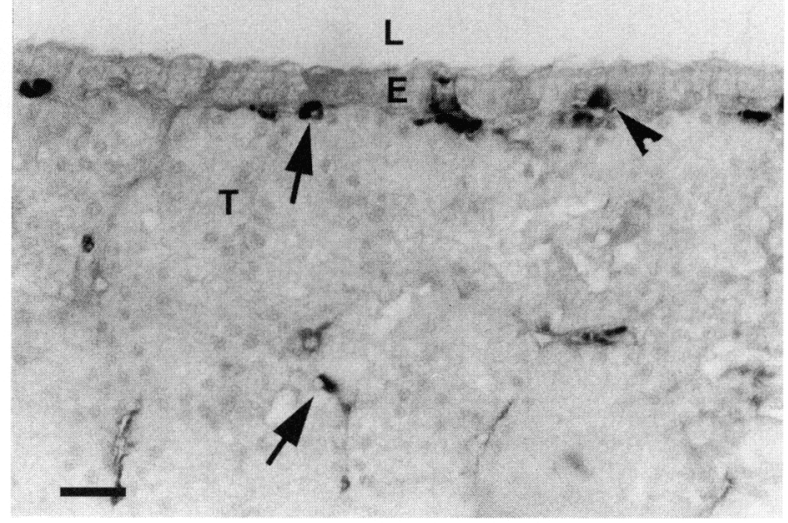

(d)
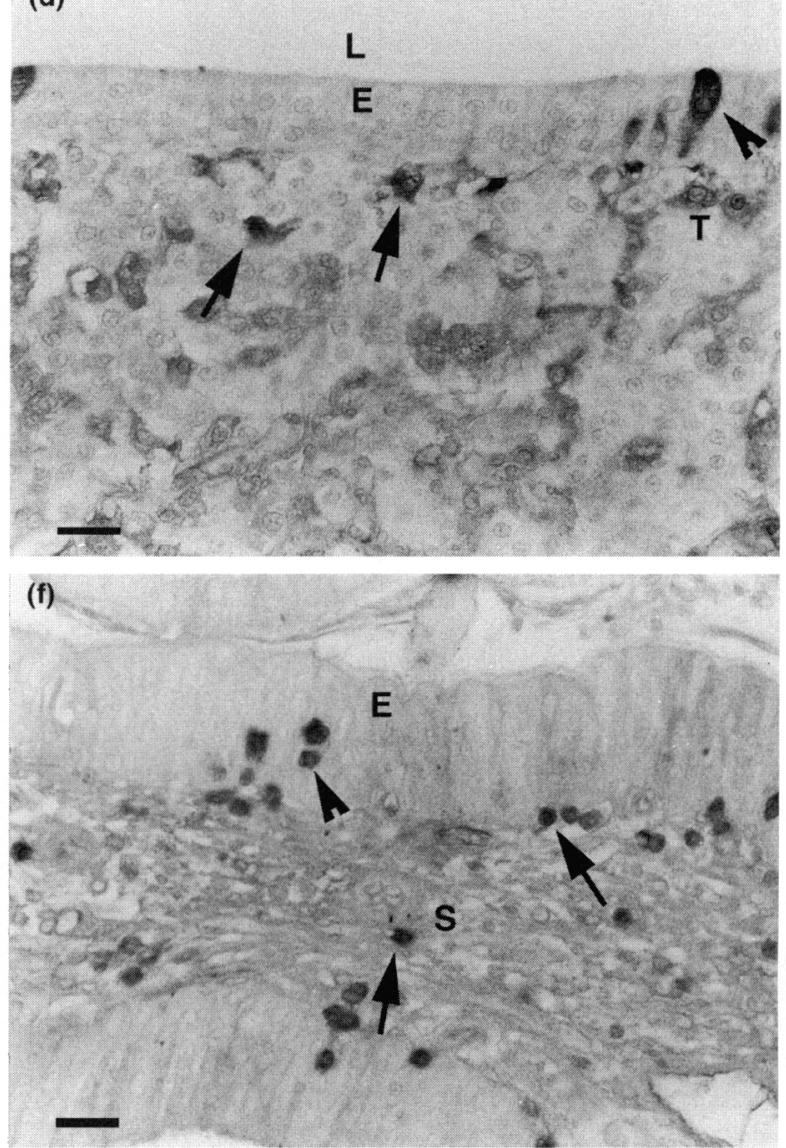

Fig. 1. Sections of the oviducts of immature and laying hens immunostained for IgG. Arrows and arrowheads indicate examples of positively stained cells in the stroma and mucosal epithelium, respectively. E: mucosal epithelium; S: stroma; $T$ : tubular gland in the stroma; L: lumen of oviduct. Scale bars represent $20 \mu \mathrm{m}$. (a) The magnum of an immature hen. There are very few IgG positive $\left(\mathrm{IgG}^{+}\right)$cells in the stroma and none in the epithelium. (b) The magnum of a laying hen. Tubular glands have developed in the stroma and positive cells are observed in the mucosal epithelium and stromal connective tissue. (c) The shell gland of an immature hen. There are very few $\operatorname{IgG}^{+}$cells in the stroma and none in the epithelium. (d) The shell gland of a laying hen. There are many positive cells in the mucosal epithelium and in the stromal connective tissue. (e) The vagina of an immature hen. There are a few $\mathrm{IgG}^{+}$cells in the stroma and none in the epithelium. (f) The vagina of a laying hen. Many $\operatorname{IgG}^{+}$cells can be seen in the mucosal epithelium and in the stroma.

was significantly higher than that of the other oviductal segments with the exception of the vagina. In immature hens, there was no significant difference in the frequency of each kind of $\mathrm{Ig}^{+}$cells in the mucosal epithelium among the oviductal segments. The frequency of $\mathrm{IgG}^{+}$and $\mathrm{IgM}^{+}$cells in the mucosal epithelium of all oviductal segments and $\lg \mathrm{A}^{+}$cells in 

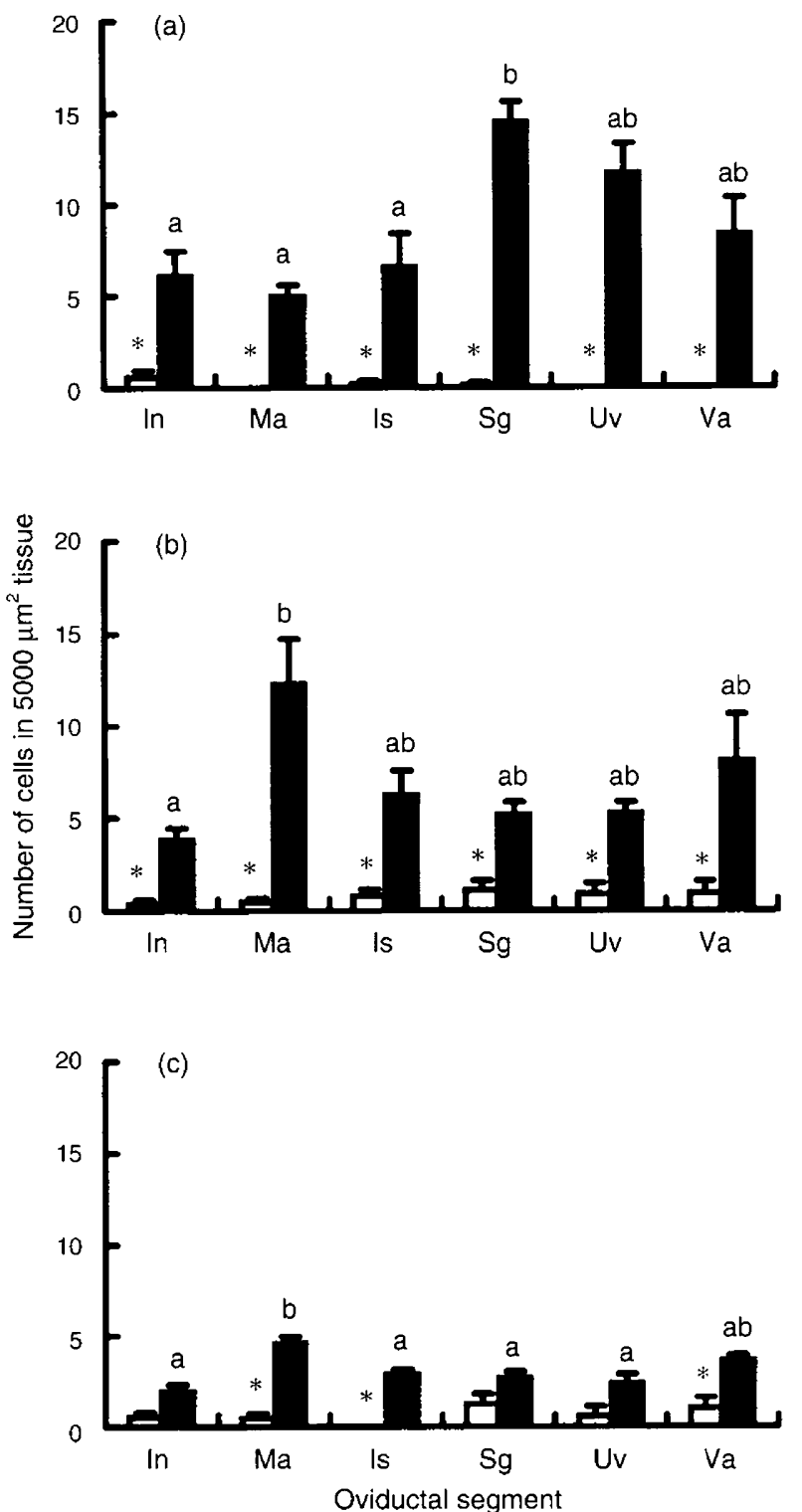

Fig. 2. Frequency of the cells positive for immunoglobulins (a) $\operatorname{IgG}$, (b) $\operatorname{IgM}$ and (c) $\operatorname{Ig} A$ in the mucosal epithelium of the oviduct in ( $\square$ ) immature and ( $\mathbf{\square})$ laying hens. Each bar represents the mean \pm SEM of the number of positive cells in $5000 \mu \mathrm{m}^{2}$ tissue $(n=5$ birds for each bar). Bars with different superscripts are significantly different $(P<0.05)$ for laying hens. There were no significant differences among the segments from immature hens. An asterisk indicates a significant difference between laying and immature birds $(P<0.05)$. In: infundibulum; Ma: magnum; Is: isthmus; $\mathrm{Sg}$ : shell gland; Uv: uterovaginal junction; Va: vagina.

the magnum, isthmus and vagina was significantly higher in laying hens than in immature birds.

The frequencies of $\mathrm{Ig}^{+}$cells in the stroma of oviductal tissues are shown (Figs 3 and 4). The populations of $\operatorname{IgG}^{+}$cells in the subepithelial stroma in the infundibulum and in the vagina were significantly higher than those in the magnum and the isthmus in the case of laying hens. In addition, the frequency of $\mathrm{IgM}^{+}$cells in the infundibulum was significantly higher than that in the magnum, and the frequencies of $\lg \mathrm{A}^{+}$
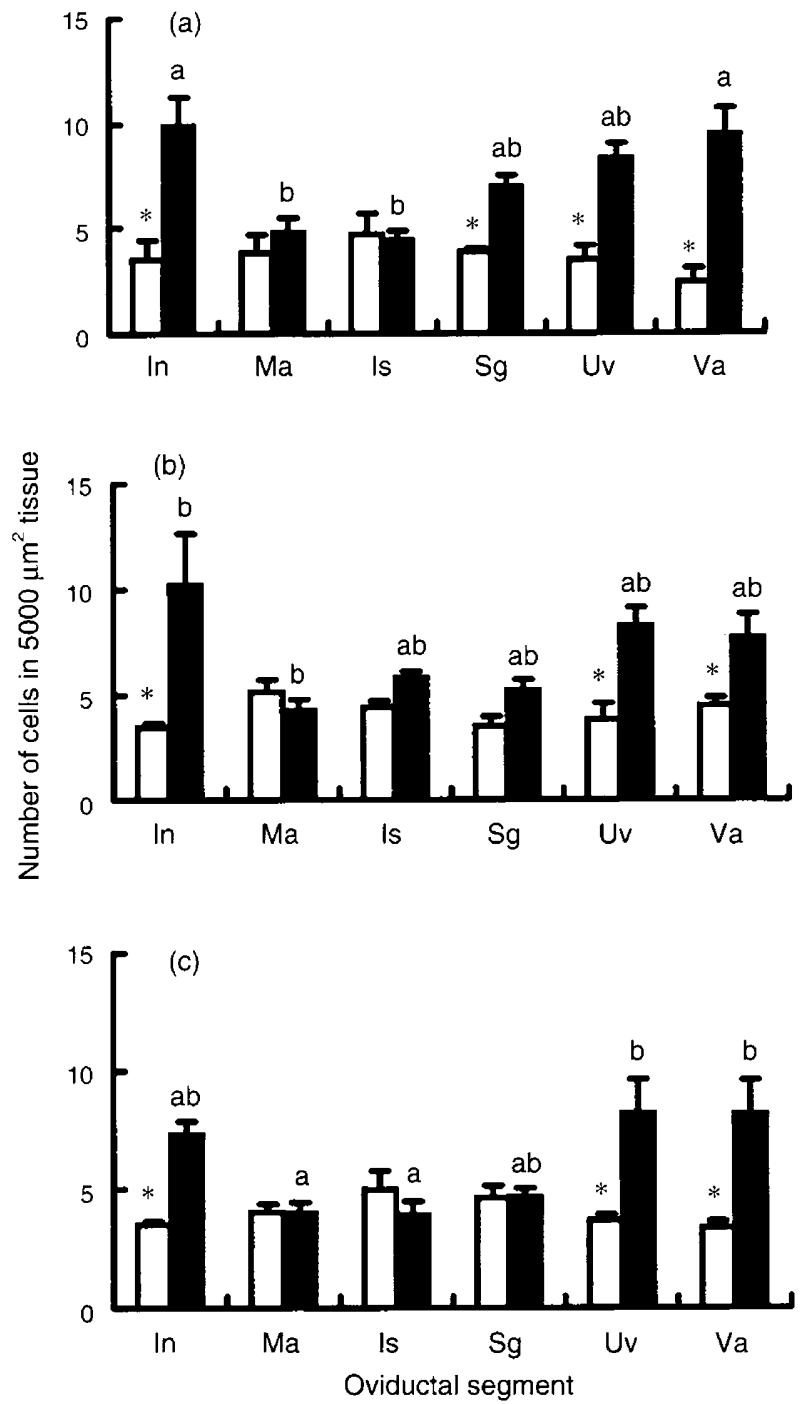

Fig. 3. Frequency of the cells positive for immunoglobulins (a) $\mathrm{IgG}$, (b) $\operatorname{IgM}$ and (c) $\operatorname{IgA}$ in the subepithelial stroma of the oviduct in ( $\square$ ) immature and ( ) laying hens. Each bar represents the mean \pm SEM of the number of positive cells in $5000 \mu \mathrm{m}^{2}$ tissue ( $n=5$ birds for each bar). For each type of immunoglobulin, bars with different superscripts are significantly different for laying hens $(P<0.05)$. There was no significant difference among the segments from immature chickens. An asterisk indicates that the difference between laying and immature birds is significant $(P<0.05)$. In: infundibulum; Ma: magnum; Is: isthmus; Sg: shell gland; Uv: uterovaginal junction; Va: vagina.

cells in the UVJ and vagina were significantly higher than those in the magnum and isthmus (Fig. 3). In the middle part of the stroma of laying hens, there were greater numbers of $\mathrm{IgG}^{+}$ and $\operatorname{IgM}^{+}$cells in the infundibulum and vagina and a greater number of $\lg \mathrm{A}^{+}$cells in the vagina than in the magnum and isthmus (Fig. 4). In immature chickens, no significant differences were detected in the frequency of each kind of $\mathrm{Ig}^{+}$cells in the subepithelial stroma among oviductal segments (Fig. 3). The frequencies of $\operatorname{IgG}{ }^{+}, \operatorname{IgM}^{+}$and $\operatorname{IgA}{ }^{+}$cells in the subepithelial stroma of infundibulum, UVJ and vagina and also that of $\mathrm{IgG}^{+}$ cells in the shell gland were significantly greater in laying hens than in immature birds (Fig. 3). 


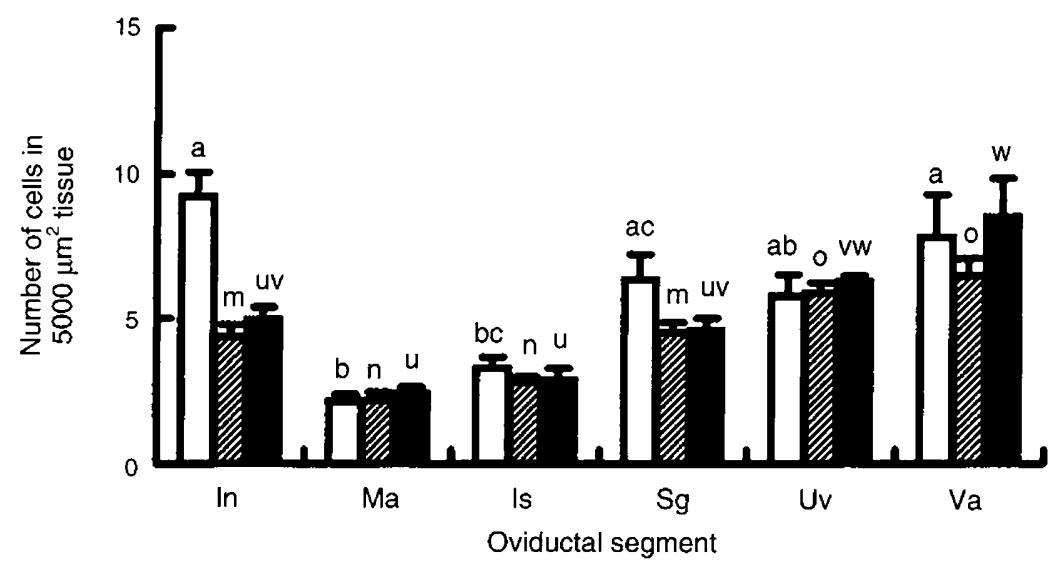

Fig. 4. Frequency of the cells positive for immunoglobulins $(\square) \operatorname{IgG}$, ( $\square$ ) $\operatorname{IgM}$ and ( $\square$ $\operatorname{Ig} A$ in the middle part of oviductal stroma of laying hens. Each bar represents the mean \pm SEM of the number of positive cells in $5000 \mu \mathrm{m}^{2}$ tissue ( $n=5$ birds for each bar). Within each type of immunoglobulin, bars with different grouped superscripts $\left({ }^{a / b / c}\right.$ for $\operatorname{IgG},{ }^{\mathrm{m} / \mathrm{n} / \mathrm{o}}$ for $\operatorname{IgM},{ }^{\mathrm{u} / \mathrm{v} / \mathrm{w}}$ for $\left.\mathrm{IgA}\right)$ are significantly different $(P<0.05)$. In: infundibulum; Ma: magnum; Is: isthmus; Sg: shell gland; Uv: uterovaginal junction; Va: vagina.

\section{Experiment 2: effects of gonadal steroids on the localization of oviductal $\mathrm{Ig}^{+}$cells in immature birds}

The mucosal tissue of the oviduct in control and progesterone-treated chicks showed an undifferentiated feature, which was similar to that seen in normal immature chickens, whereas in DES-treated chicks, the mucosal tissue showed a developed structure including the formation of tubular glands in the magnum and shell gland (Fig. 5). Plasma cell-like cells positive for $\operatorname{IgG}$, IgM and $\operatorname{IgA}$ were observed in the stromal connective tissue of all oviductal segments in chickens treated with oil, DES or progesterone (Fig. $5 a-f$ ), and a few of the mucosal epithelial cells also stained positive for $\lg G, \operatorname{IgM}$ and $\operatorname{Ig} \mathrm{A}$.

The frequencies of $\operatorname{IgG}^{+}, \operatorname{IgM}^{+}$and $\operatorname{IgA}{ }^{+}$cells in the oviductal mucosal epithelium and stroma of chickens treated with oil, DES or progesterone are shown (Figs 6 and 7). In the mucosal epithelium, the effect of treatment with DES on the population of $\mathrm{IgG}^{+}$cells was not significant. However, the frequency of $\operatorname{lgM}^{+}$cells in the mucosal epithelium of all oviductal segments and that of $\operatorname{IgA}{ }^{+}$cells of the magnum were significantly increased by DES treatment. Progesterone treatment had no significant effect on the frequency of $\mathrm{Ig}^{+}$ cells in the mucosal epithelium. The population of $\operatorname{IgA}{ }^{+}$cells in the mucosal epithelium of the DES-treated group was significantly greater in the magnum than in the shell gland and vagina (Fig. 6).

A significant increase in the population of $\mathrm{IgG}^{+}$cells was observed in the oviductal stroma of the shell gland and vagina, and of $\operatorname{lgM}^{+}$cells in the vagina as a result of treatment with DES (Fig. 7). Treatment of chickens with progesterone had no significant effect on the populations of $\mathrm{Ig}^{+}$cells in the oviductal stroma with the exception of the population of $\mathrm{IgM}^{+}$cells in the shell gland which was significantly decreased by treatment. In DES-treated birds, the population of $\operatorname{lgG}{ }^{+}$ cells was approximately $2-4$ times higher than those of $\operatorname{IgM}^{+}$ and $\operatorname{IgA}{ }^{+}$cells in the magnum, shell gland and vagina. In addition, the populations of $\mathrm{IgG}^{+}$cells were not significantly different among the magnum, shell gland and vagina, whereas the population of $\operatorname{IgM}^{+}$cells in the vagina was significantly higher than in the magnum and shell gland, and that of $\operatorname{Ig} \mathrm{A}^{+}$ cells was significantly higher in the shell gland and vagina than in the magnum.

\section{Discussion}

The significant findings of the present study are that there are significantly more $\mathrm{Ig}^{+}$cells in both the mucosal epithelium and stroma of the oviducts of laying hens than in immature chickens, and that stilboestrol, an analogue of oestrogen, significantly increases the population of oviductal $\mathrm{Ig}^{+}$cells in immature hens, while progesterone has no such effect.

The $\mathrm{Ig}^{+}$cells are localized in the cells of mucosal epithelium and plasma cell-like cells in both the subepithelial and the middle part of stroma in laying hens. This observation supports previous reports which localized $\mathrm{Ig}^{+}$cells in the oviductal stroma (Lebacq-Verheyden et al., 1972; Van Krey et al., 1987; Kirk et al., 1989; Kimijima et al., 1990) and mucosal epithelium (Kimijima et al., 1990) in laying hens. It is not known whether the mucosal epithelial cells produce immunoglobulins or if they absorb them from blood or plasma cell-like cells localized in the subepithelial stroma. Immunoglobulins secreted from the epithelium into the oviductal lumen may act locally. It has been reported that in laying hens infected with Salmonella enteritidis the level of infection was much lower in the oviduct than in the intestine, even though the vagina opens to the cloaca, and also that contamination of the egg components was much less than that on the surface of the eggshell (Shivaprasad et al., 1990; Poppe et al., 1992). The presence of many $\mathrm{Ig}^{+}$cells in the stroma of both ends of the oviduct may protect the oviduct from infection by bacteria and other pathogens. Barr and Parr (1985) demonstrated that, in mammals, $\operatorname{IgA}, \operatorname{IgG}$ and possibly $\operatorname{IgM}$ bind to many of the bacteria in the luminal contents of the 

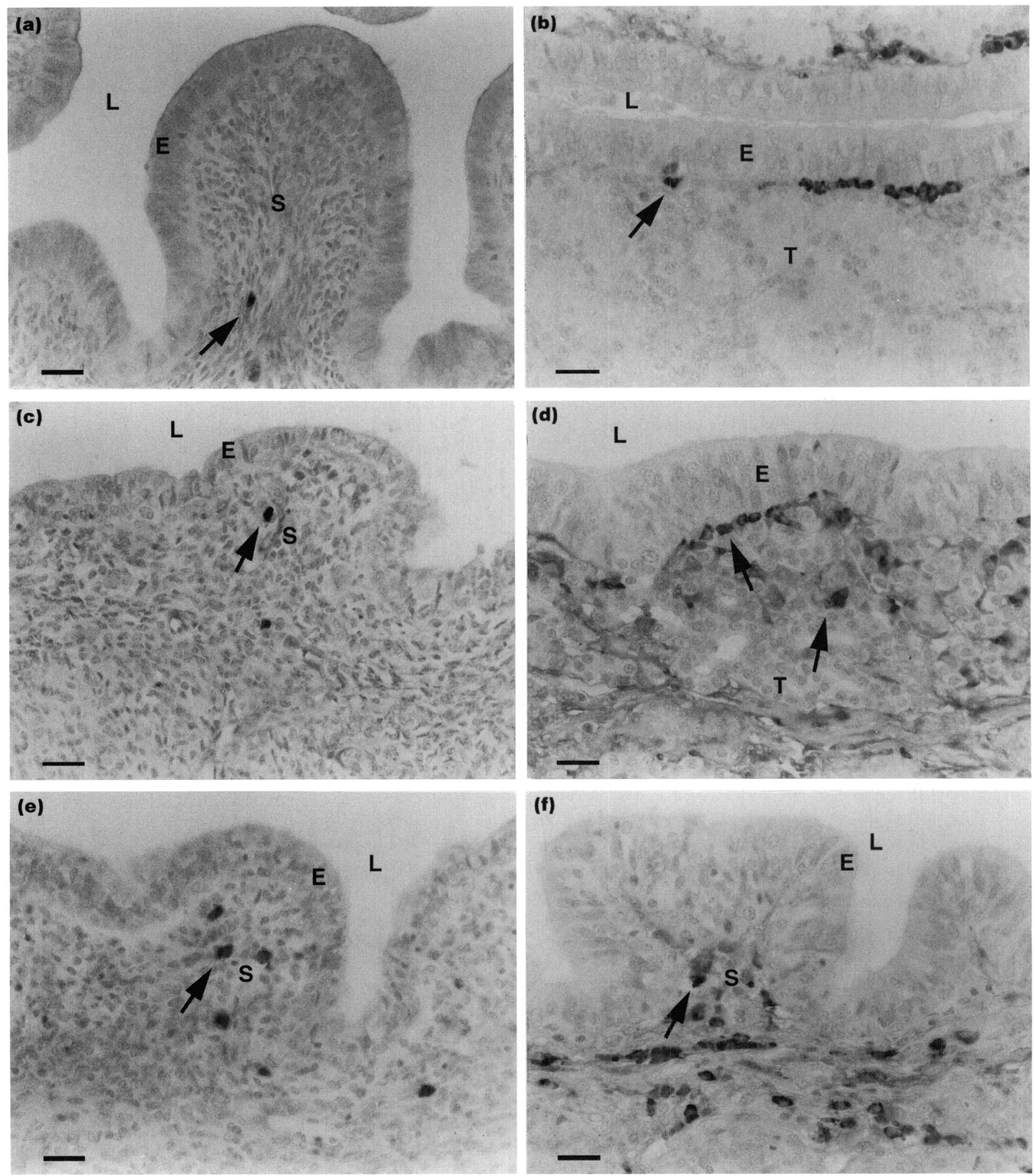

Fig. 5. Sections of the magnum, shell gland and vagina of immature chickens treated with stilboestrol and control sections immunostained for IgG. Arrows indicate examples of positive cells in the stroma. E: mucosal epithelium; S: stroma; T: tubular gland in the stroma; L: lumen of the oviduct. Scale bars represent $20 \mu \mathrm{m}$. (a) The magnum of a control chick. There are very few IgG positive $\left(\mathrm{IgG}^{+}\right.$) cells and no tubular glands have formed in the stroma. (b) The magnum of immature bird treated with stilboestrol. Note the presence of many positive cells and the formation of tubular glands in the stroma. (c) The shell gland of a control bird. Only a few positive cells are present. (d) The shell gland of the immature bird treated with stilboestrol. There are more positive cells compared with the control section and tubular glands have developed in the stroma. (e) The vagina of a control bird. Only a few positive cells are observed in the stroma. (f) The vagina of an immature bird treated with stilboestrol. Note the increased number of $\operatorname{lgG}^{+}$cells compared with the control section.

uterus. They also suggested that the secretory immune system in the reproductive tract of female mice may be involved in returning the uterus to an aseptic state by at least three mechanisms, namely the blocking of the bacteria-binding sites of the mucosal epithelium, the agglutination of bacteria and the opsonization of bacteria in preparation for phagocytosis. The 

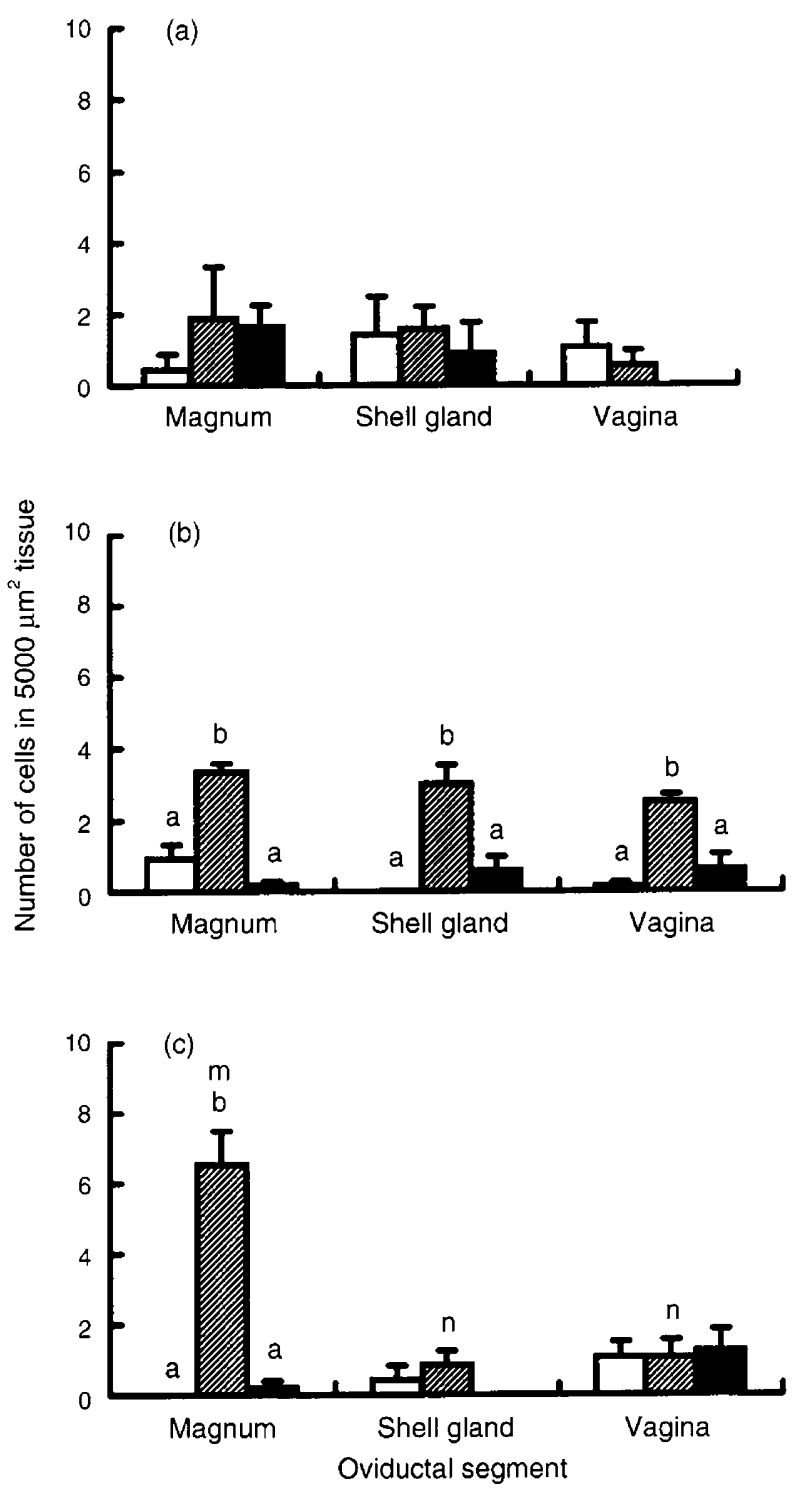

Fig. 6. Frequency of the cells positive for immunoglobulins (a) $\operatorname{IgG}$, (b) $\operatorname{IgM}$ and (c) $\operatorname{IgA}$ in the mucosal epithelium of the oviduct in immature chickens treated with ( $\square$ ) stilboestrol (DES) or $(\square)$ progesterone. ( $\square$ ) Control. Each bar represents the mean \pm SEM of the number of positive cells in $5000 \mu \mathrm{m}^{2}$ tissue ( $n=6$ birds for each bar). Within each oviductal segment, bars with different superscripts are significantly different $(P<0.05)$. (c) In the DES-treated birds, bars with superscripts $\mathrm{m} / \mathrm{r}$ are significantly different for the frequency of $\operatorname{IgA}{ }^{+}$cells $(P<0.05)$.

infundibulum, UVJ and vagina are closely related to fertilization, storage and selection of spermatozoa in hens (Fujii, 1963; Fujii and Tamura, 1963; Bakst et al., 1994). Recent reports have indicated that there is an increase in the number of leukocytes in the lumen of the vagina just after insemination and that phagocytosis of spermatozoa by oviductal cells occurs in UVJ (Higaki et al., 1995), suggesting that an anti-sperm immunoreaction occurs in the oviduct of hens. Steele and Wishart (1992) reported that spermatozoa recovered from the vagina carried Igs, suggesting that Igs may affect the survival, or are involved in the immunological selection, of spermatozoa in the
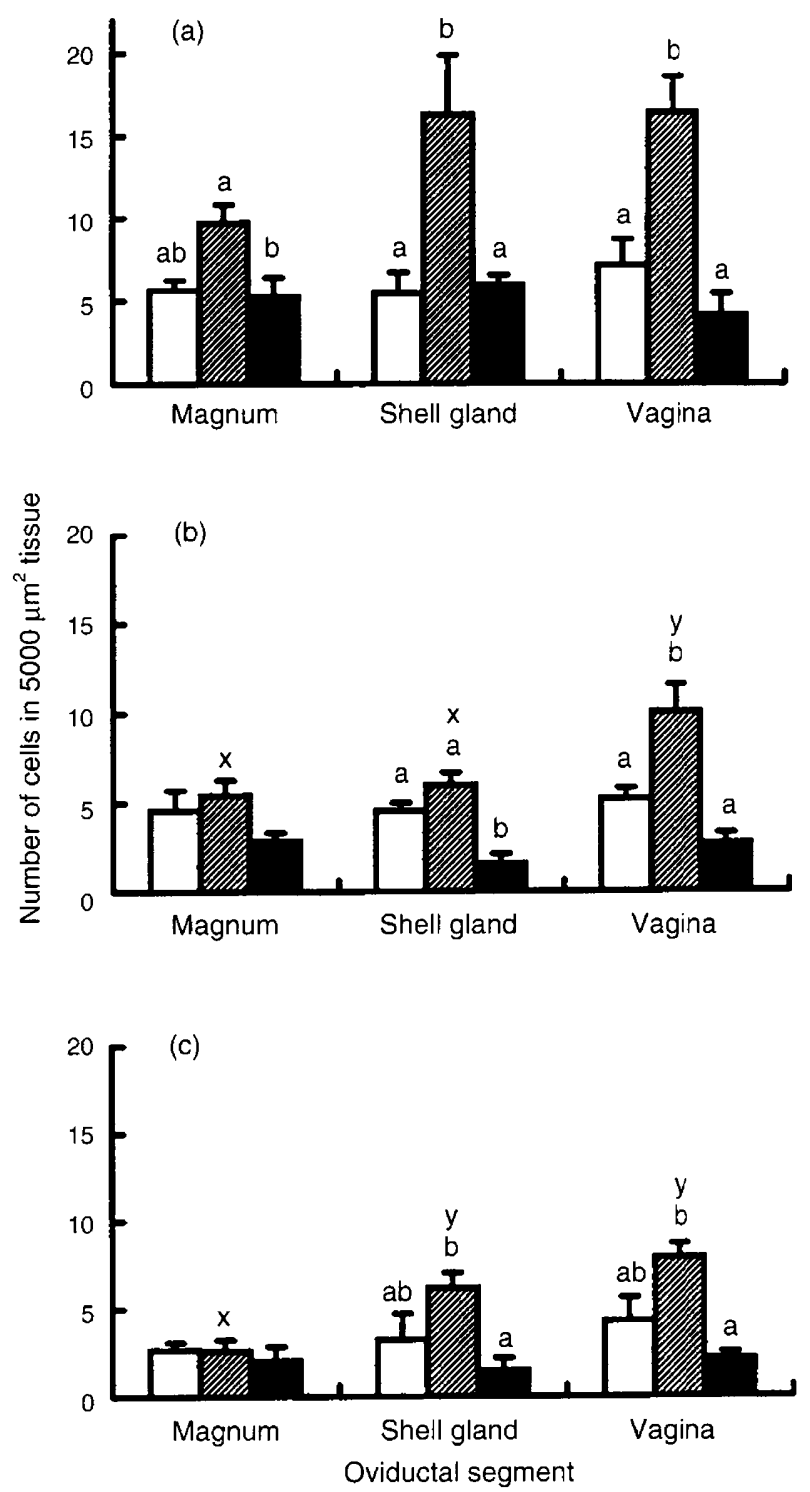

Fig. 7. Frequency of the cells positive for immunoglobulins (a) $I g G$, (b) $\operatorname{lgM}$ and (c) $\operatorname{Ig} A$ in the subepithelial stroma of the oviduct in immature chickens treated with ( $Z$ ) stilboestrol (DES) or ( $\square$ ) progesterone. ( $\square$ ) Control. Each bar represents the mean \pm sEM of the number of positive cells in $5000 \mu \mathrm{m}^{2}$ tissue $(n=6$ birds for each bar). Within each oviductal segment, bars with different superscripts are significantly different $(P<0.05)$. In birds treated with stilboestrol, bars with superscripts ${ }^{x / y}$ are significantly different in the frequency of (b) $\operatorname{IgM}$ or (c) IgA positive cells $(P<0.05)$.

oviduct. Immunoglobulins in the vagina, UVJ and infundibulum may participate in these anti-sperm immunoreactions as most spermatozoa remain in these parts of the reproductive tract just after insemination (Bakst et al., 1994; Higaki et al., 1995). Therefore, we suggest that the infundibulum, UVJ and vagina contain greater numbers of $\mathrm{Ig}^{+}$cells, and that these segments play an important role in the immune responses to both pathogenic agents and spermatozoa.

The present results show that there were more $\mathrm{Ig}^{+}$cells in the infundibulum, shell gland, UVJ and vagina of laying hens than in these areas of immature birds. Treatment of immature 
birds with DES increased the number of $\operatorname{IgM}^{+}$cells in the mucosal epithelium in all oviductal segments, of $\operatorname{Ig} \mathrm{A}^{+}$cells in the mucosal epithelium of the magnum, of $\mathrm{IgG}^{+}$cells in the stroma of the shell gland and vagina, and of $\operatorname{IgM}^{+}$cells in the stroma of the vagina. Progesterone had no effect. We previously reported that the population of $\mathrm{IgG}^{+}$cells, as well as $\mathrm{T}$ cells ( $\mathrm{CD} 3$ positive cells) and $\mathrm{B}$ cells (Bu- $1 \mathrm{~b}$ positive cells) was greater in laying hens than in moulting hens (Yoshimura et al., 1996). These results indicate that the increase in $\mathrm{Ig}^{+}$cells during sexual maturation is closely associated with oviductal growth which is possibly under the control of oestrogen. Leitner et al. (1996) demonstrated that the administration of oestrogen to hens significantly enhanced the humoral immune response to Escherichia coli and sheep erythrocytes, whereas treatment with an anti-oestrogen strongly inhibited these immune responses. Therefore, oestrogen may increase the humoral immune response and also local immunity in the specific organs that are the targets for oestrogen, like the oviduct. The population of $\operatorname{IgM}^{+}$cells in the shell gland was lower in progesterone-treated birds than in control birds. Although we did not examine the effects of progesterone on the $\mathrm{Ig}^{+}$cell population in the oviducts of laying hens or DES-treated birds, progesterone may suppress the infiltration of $\mathrm{Ig}^{+}$cells into the oviduct. Studies in mammais have also provided evidence that gonadal steroids might play a significant role in immune function (Trawick and Bahr, 1986; Erbach and Bahr, 1988, 1991). Wira and Sandoe (1980) reported that oestrogen increased uterine $\operatorname{Ig} A$ and $\operatorname{IgG}$ concentrations in ovariectomized or hypophysectomized rats and that the spontaneous increase of Ig concentrations during the oestrous cycle resulted from the action of oestrogen in the uterus. Wang et al. (1996) reported that the transport of polymer lgA from the blood into female mouse genital tissues decreased significantly after ovariectomy, and that this decline was rectified by oestradiol but not by progesterone. The effects of progesterone on the $\mathrm{Ig}^{+}$cells in the hen's oviduct need to be examined further.

In conclusion, the present results suggest that the local immunity in the oviduct develops during sexual maturation and is under the control of oestrogen. The presence of relatively greater numbers of $\mathrm{Ig}^{+}$cells in both ends of the oviduct suggests that the immune system in these tissues plays an important role in the immune response to pathogenic agents and spermatozoa.

This work was supported by Grant-in-Aid for Scientific Research from the Ministry of Education, Science and Culture of Japan (No. 08660346) to Y. Yoshimura.

\section{References}

Bakst MR, Wishart G and Brillard JP (1994) Oviducal sperm selection, transport and storage in poultry Poultry Science Reviews 5 117-143
Barr EL and Parr MB (1985) Secretory immunoglobulin binding to bacteria in the mouse uterus after mating Journal of Reproductive Immunology 8 7I-82

Burke WH and Rieser JW (1972) The effects of anti-sperm antisera and uterine fluids on the fertilizing ability of turkey spermatozoa Poultry Science 51 190-195

Burke WH and Yu WCY (1979) Infertility in the turkey. I. Effects of anti-sperm immune globulins on fertilizing ability of turkey spermatozoa Poultry Science 58 1367-I371

Erbach GT and Bahr JM (1988) Effect of chronic or cyclic exposure to estradiol on the humoral immune response and the thymus Immunopharmacology 16 45-51

Erbach GT and Bahr JM (1991) Enhancement of in vivo humoral immunity by oestrogen: permissive effect of a thymic factor Endocrinology $\mathbf{1 2 8}$ 1352-1358

Fujii S (1963) Histological and histochemical studies on the oviduct of the domestic fowl with special reference to the region of uterovaginal juncture Archioum Histologicum Japonicum 23 447-459

Fujii S and Tamura T (1963) Location of sperm in the oviduct of the domestic fowl with special reference to storage of sperm in the vaginal gland Journal of the Faculty of Fisheries and Animal Husbandry, Hiroshima University 5 145-163

Grossman CJ (1984) Regulation of the immune system by sex steroids Endocrine Reviews 5 435-455

Higaki K, Yoshimura Y, Tamura T and Okamoto T (1995) Localization of spermatozoa and leukocytes in vagina and uterovaginal junction after copulation in Japanese quail (Coturnix coturnix japonica) Japanese Poultry Science 32 387-393

Kimijima T, Hashimoto Y, Kitagawa H, Kon Y and Sugimura M (1990) Localization of immunoglobulins in chicken oviduct Japanese Journal of Veterinary Science 52 299-305

Kirk TA, Van Krey HR, Hulet RM, Dunnington EA and Denbow DM (1989) The relationship of infertility to antibody production in the uterovaginal sperm storage tubules of turkey breeder hens Theriogenology 31 955-961

Lebacq-Verheyden AM, Vaerman JP and Heremans JF (1972) Immunohistologic distribution of the chicken immunoglobulins Journal of Immunology 109 $652-654$

Leitner G, Landsman T, Blum O, Zaltsmann N and Heller ED (1996) Effects of gonadal steroids and their antagonists on the humoral immune response of immune selected broiler chicks Poultry Science 75 1373-1382

Poppe C, John RP, Forsberg CM and Irwin RJ (1992) Salmonella enteritidis and other Salmonella in laying hens and eggs from flocks with Salmonella in their environment Canadian Journal of Veterinary Research 56 226-232

Shivaprasad HL, Timoney JF, Morales S, Lucio B and Baker RC (1990) Pathogenesis of Salmonella enteritidis infection in laying chickens. I. Studies on egg transmission, clinical signs, fecal shedding, and serologic responses Avian Diseases $34 \quad 548-557$

Steele MG and Wishart GJ (1992) Evidence for a species-specific barrier to sperm transport within the vagina of the chicken hen Theriogenology $\mathbf{3 8}$ 1107-1114

Trawick DR and Bahr JM (1986) Modulation of the primary and secondary antifluoresceyl antibody response in rats by $17 \beta$-estradiol Endocrinology 118 2324-2330

Van Krey HP, Schuppin GT, Denbow DM and Hulet RM (1987) Turkey breeder hen infertility associated with plasma cells in the uterovaginal sperm storage glands Theriogenology 27 913-92I

Wang YQ, Ben KL, Cao XM and Wang YM (1996) Transport of anti-sperm monoclonal $\operatorname{IgA}$ and $\operatorname{IgG}$ into murine male and female genital tracts from blood Journal of Immunology 156 1014-1019

Wira RC and Sandoe PC (1980) Hormonal regulation of immunoglobulins: influence of estradiol on immunoglobulins $A$ and $G$ in the rat uterus Endocrinology 106 1020-1026

Yoshimura X, Higaki K, Tamura T and Okamoto T (I996) Studies on the immune function in hen oviduct with reference to sperm survival Proceedings of the 8 th AAAP Animal Science Congress Vol. 2 126-127 